\title{
A COMISSÃO INTERNACIONAL DE HISTÓRIA MARÍTIMA $\left({ }^{\star}\right)$.
}

A Comissão Internacional de História Marítima foi criada por uma decisão da Assembléia Geral do Comitê Internacional das Ciências Históricas, realizada em Upsala, a 29 de agôsto de 1960, por ocasião do XII Congresso Internacional de História.

Os Estatutos e a organização da Comissão foram fixados durante o $\mathrm{V}$ Colóquio Internacional de História Marítima, reunido em Lisboa de 14 a 16 de setembro de 1960 .

A origem da Comissão se prende a um voto formulado do $\mathrm{X}$ Congresso Internacional das Ciências Históricas, realizado em Roma, em setembro de 1955; êsse voto preconizava a renovação, de maneira ampla, da antiga Comissão Internacional para a "História dos Grandes Descobrimentos" que, com a Segunda Guerra Mundial, desaparecera.

Desde 1955, várias iniciativas vinham sendo tomadas e seu êxito militava em favor da criação da Comissão. As realizações foram estas: o início da revisão do "Glossário Náutíco" de A. Jal, obra mais que centenária; a reunião em Paris de quatro colóquios internacionais de História marítima em 1956, 1957, 1958 e 1959, e, finalmente, em Lisboa, em setembro de 1960, de um quinto colóquio, particularmente brilhante.

Desde a sua criação, a Comissão mantém correspondentes nos diversos continentes: várias sub-comissões nacionais estão organizadas ou em vias de serem organizadas. Dois grupos de trabalho estão em plena atividade: um, que tem por objeto a revisão do "Glossário Náutico" de Jal; outro, se propôs retomar a "Bibliografia da História dos Descobrimentos" sob forma de uma "Bibliografia das Grandes Rotas Oceânicas".

Dois outros grupos estão por se formar, tendo, respectivamente, por objeto a arqueologia submarina e a Edição dos 
principais textos da "História do Direito e das Instituições Marítimas".

Por outro lado, experiências que visam à utilização dos métodos mecanográficos I. B. M. para o estudo quantitativo do tráfico marítimo foram coroadas de êxito.

A Comissão tenciona, também, organizar um Catálogo Internacional dos Museus, coleções e bibliotecas de História marítima.

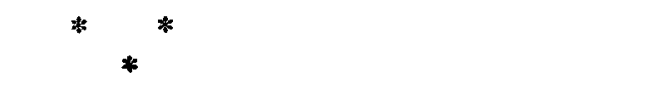

\section{ESTATUTOS}

Da Comissão Internacional de História Marítima (adotados no V Colóquio Internacional de Lisboa - 14 de setembro de 1960).

1. - A Comissão Internacional de História Marítima tem por objeto estabelecer contactos e facilitar a coordenação das pesquisas entre especialistas de todos os ramos da História Marítima. Continuadora da antiga Comissão Internacional de História dos Grandes Descobrimentos, ela inclui, no seu programa de trabalho, a história da expansão ultramarina em tôdas as suas formas.

2. - A Comissão organizou-se em comissão interna do Comitê Internacional das Ciências Históricas, segundo as disposições definidas por êste Comitê em Roma, a 2 de setembro de 1955 e em Lausanne, a 19 de junho de 1956. Ela se elege por cooptação. Seu Secretariado é nomeado por 5 anos, por ocasião do Congresso Internacional Quinquenal das Ciências His-, tóricas. O mandato de seus membros poderá ser renovado.

3. - O Comitê da Comissão é composto de Secretariado, conselheiros e representantes das sub-comissões nacionais e dos grupos de trabalho especializados.

4. - Os Grupos de trabalho constituem-se no interior da Comissão para a realização de certas tarefas definidas, tais como a revisão do "Glossário Náutico" de A. Jal; a continuação da bibliografia da "História dos Grandes Caminhos Oceânicos"; a publicação dos principais textos e atos da prática relativos ao direito do mar; as pesquisas arqueológicas; a instituição de instrumentos de trabalho (lista dos Museus e coleções marítimas...), etc.

5. - Agrupamentos, Sociedades ou Instituições que exercem uma atividade análoga àquela da Comissão podem ser ad- 
mitidos, por decisão do Secretariado, associando-se a ela a título de filiados ou correspondentes.

6. - A Comissão promove colóquios internacionais com 0 : concurso das sub-comissões nacionais.

7. - O Secretariado da Comissão redige um Boletim para manter o contacto entre os seus membros, informando-os è coordenando-lhes os trabalhos.

\section{** \\ LISTA DOS MEMBROS DO SECRETARIADO (outubro de 1960).}

Presidente de Honra: Sr. Roberto Almagià, Professor da Universidade de Roma.

Vice-Presidente 'de Honra: Sr. Robert Ricard, Professor da Sorbonne.

Presidente: Sr. Michel Mollat, Professor da Sorbonne - 1; rue Bausset - Paris XVe.

Vice-Presidentes: Srta. Virgínia Rau, Professôra da Universidade de Lisboa - 75, Avenida da República, Lisboa. Sr. Charles Verlinden, Professor da Universidade de Gand, Diretor da "Academia Belgica", Via Omero, 8 - Roma.

Assessores: Sr. Georges P. B. Naish, Secretário Honorário da Society for National Nautical Research, Maritime Museum, Greenwich SE. 10. Dr. Sílvio Zavala, Presidente da Comissão de História do Instituto Pan-Americano de Geografia e de História, Delegado permanente do México na UNESCO - Paris.

Secretário Geral: Paul Adam, 17 rue Gabriel Péri. Igny (S. et O.):

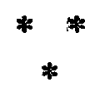

CORRESPONDENTES E GRUPOS NACIONAIS.

Para que a Comissão Internacional de História Marítima cumpra o seu papel de intermediária entre os pesquisadores 
de diferentes países, é necessário estabelecer um contacto sob. uma ou outra forma, seja com os correspondentes, seja com as sub-comissões nacionais. O movimento é assim dirigido e êstes são os primeiros resultados:

Alemanha: O contacto é estabelecido com a "Hanssische Gestchichtsverein" e, mais particularmente, a título de corresponte, com o:

Cmte. Heinsius (Hamburgo);

Prof. P. Johansen (Universidade de Hamburgo);

Prof. H. Kellenbenz (Universidade de Colônia);

Prof. H. Sproemberg (Universidade de Berlim).

Bélgica: Sr. Ch. Verlinden (do Secretariadn, Prof. da Universidade de Gand e Diretor da "Academia Belgica", em Roma.

Brasil: Uma Sub-Comissão constituída pelos:

Prof. W. Ferreira (Universidade de São Paulo);

Prof. T. O. Marcondes de Souza (Universidade de São Paulo);

Almte. A. Messiano (Rio de Janeiro);

Secretário: Profa. Miriam Ellis (Universidade São Paulo);

Secretário-adjunto: Prof. J. R. do Amaral Lapa (Faculdade de Filosofia, Ciências e Letras de Marília).

Dinamarca: Profa. Astrid Friis (Universidade de Copenhague).

Espanha: Nosso correspondente, Almirante J. Guillen y Tato, Secretário Perpétuo da Real Academia (Madrí), prepara a. constituição de uma Comissão Nacional.

Estados Unidos: Uma Sub-Comissão constituída pelos Srs.:

Prof. Vernoni D. Tate (Naval Academy, Annapolis);

Prof. F. C. Lane (John Hopkins University, Baltimore);

Prof. W. Whitehill (The Atheneum, Boston);

Prof. W. Leland (Washington).

França: Além dos contactos estabelecidos com a Academia da Marinha, aceitou ser correspondente o Comitê de Documentação Histórica da Marinha, que largamente havia participado :dos primeiros Colóquios de História Marítima (o primeiro teve lugar em Paris, em 1956). 
Grã-Bretanha: Sr. G. P. B. Naish, Secretário da. Nautical Research Society, Londres;

Prof. J. S. Bromley (Universidade de Southampton).

Estabeleceram-se contactos para a Revisão do JAL com a Society for Nautical Research e o National Maritime Museum de Greenwich.

Grécia: Prof. C. Tn. Dimaras, diretor da Fundação Real da Pesquisa Científica Helênica;

Almirante D. Phocas, membro da Academia' de Atenas, que aceitou a presidência de uma Comissão encarregada da revisão do vocabulário marítimo grego (vinculando-se à Revisão do JAL). O trabalho é efetuado sob a direção do Prof. Dimaras, com a colaboração da Sra. Coumariano (do Centro de Pesquisas Neo-Helênico) e do Cmte. Athanassiadis (Prof. da Escola dos Altos Estudos Econômicos e Comerciais).

Ilha Maurício: Dr. A. Toussaint, Diretor dos Arquivos, Presidente da Associação Histórica Internacional do Oceano fndico.

Itália: Prof. G. Luzzatto (Universidade de Veneza);

Prof. F. Mells (Universidade de Pisa);

Prof. A. Tennenti (Universidade de Florença).

Ficou assegurado um estreito contacto com a Fondazione Cini, especialmente para organizar o $6 .^{\circ}$ Colóquio Internacional de História Marítima. Por intermédio do prof. M. Gabriele estabeleceu-se contacto com a Marinha Italiana, visando à constituição de um Comitê italiano .

Noruega: O Comitê das Ciências Históricas encarregou o dr. J. N. Tommesen (Glads vei 33, Grefsen, Oslo) de representá-lo junto à Comissão Internacional e de preencher as funções de correspondente.

Países-Baixos: Uma Sub-Comissão de História Marítima foi assim constituída:

Presidente: dr. R. Wber (Museu Postal de Amsterdão);

Secretária: Srta. A. M. P. Mollema.

A Sub-Comissão deu origem a uma sociedade que já conta com mais de sessenta membros.

Polônia: Sr. M. Malowist, Professor da Universidade de Varsóvia; 
Sr. C. Lepszy; Professor da Universidade de Cracóvia.

Assegurou-se um contacto com o. "Biuletyn Nautologiczny", publicado em Gdansk (dr. R. Drapella).

Portugal: A Srta. Virginia Rau, Profa. da Universidade de Lisboa e o Cmte. Telixeira da Mota aceitaram a incumbência de coordenar os esforços dos diferentes órgãos de pesquisas, conjuntamente com o dr. Silva Rêgo (Centro de Estudos Históricos Ultramarinos), tanto para a revisão do JAL como para a Bibliografia da História dos grandes caminhos oceânicos. sala.

Suécia: Sr. Hildebrant, Professor da Universidade de Up-

Turquia: Sr. Omar L. Barkan, Professor da Universidade de Istambul.

Iugoslávia: Sr. J. Tadic, Professor da Universidade de Belgrado.

Esta é a parte que concerne, evidentemente, aos grupos de trabalho, às comissões ou aos Institutos, pois numerosos são os países em que deverão concretizar-se os contactos individuais, para um mínimo de organização necessária a uma colaboração efetiva.

A Associação Histórica Internacional do Oceano fndico, que desde 1960 congrega historiadores de todos os países litorâneos dêste Oceano, pediu sua inscrição à Comissão, dado que uma notável parte da sua atividade corrseponde ao nosso programa. E' presidente dessa Associação o Sr. A. Toussaint, Arquivista da Ilha Maurício e é seu secretário geral o sr. A. Scherer, Arquivista de La Reunion. Os Srs. A. Toussaint e Lombard, animadores da A. H. I. O. I. fazem parte do nosso Comitê.

\section{REVISÃO DO GLOSSARIO NAUTICO DE JAL.}

As reuniões realizadas em Estocolmo e em Lisboa, em 1960, permitiram trocas de vistas no plano internäcional; por outro lado, muitas reuniões de trabalho realizaram-se em Paris; e 
as indicações que se seguirem serão o resultado dessas discus-: sões. Tais discussões grupar-se-ão em tôrno de dois centros prinn-, cipais de interêsse:

1). - Categoria de nomes a inserir ou a rejeitar no nôvó Glossário.

2) . - Sistema de cooperação dos grupos nacionais e problemas colocados pelas diversas línguas.

I) . - Nomes de Peixes. - Se nos propuséssemos ao levantamento dos nomes de peixes e de outros animais marinhos, correríamos o risco de nunca acabar: primeiro, a zoologia por si só constitui um mundo... (e porque, então, não acrescentar também a botânica marítima?...); em segundo lugar, os próprios peixes têm, ainda em nossos dias $\epsilon$ conforme os lugares, nomes diversos, que pouco interêsse teriam para 0 historiador consulente do Glossário.

Em compensação, há certos peixes particularmente impor-, tantes para a economia marítima ou mesmo para a arquitetura naval. Como falar dos "arenqueiros" ou dos "bacalhoeiros" sem dizer algo do "arenque" ou do "bacalhau"?

Trataríamos, pois, de conservar, ùnicamente, os nomes daquêles peixes que tiveram uma real importância econômica, limitando-nos a dar as indicações de ordem histórica, que permitiriam compreender, por exemplo, como e em que época o "bacalhau" provocou a construção de um barco especialmente idealizado para a pesca dêsse peixe.

Nomes de instrumentos de pesca. - O problema dos nomes de instrumentos de pesca é inteiramente diverso daquele que pomos para o dos peixes. Diferentemente da zoologia, abordamos, neste capítulo, uma questão de verdadeira técnica márítima. Se o peixe não adquire importância para nós senão a partir do momento em que é retirado da água e pôsto em terra, prestes a ser consumido, os instrumentos de pesca estão ligados aos homens que os utilizam e aos barcos de que se servem (sem falarmos, evidentemente, dos instrumentos fixos ou, móveis dos "pescadores a pé", segundo a tradicional e administrativa expressão utilizada na França).

Ao examinarmos, por exemplo, um texto da Idade Média que mencione, ainda que ocasionalmente, navios de pesca, corremos o risco de encontrar um nome de instrumento que muito provàvelmente será difícil identificar, mas cujo significado preciso permitiria muitas vêzes tirar uma indicação suplemen- 
tar de um texto talvez sumário e de interpretação sutil. E' verdade que os dicionários atuais, e o JAL de maneira especial, são muito pobres na matéria. E' evidente que mesmo os esforços conjugados de todos os colaboradores que quiserem dedicar-se à matéria, não hão de reunir e explicar senão uma parte dos nomes dêsses instrumentos... A perfeição é impossível. Devemos, no entanto, tentá-la. Com êsse propósito, decidimonos recolher o maior número possível de nomes de instrumentos de pesca e integrá-los no JAL.

Nomes dos tipos de navios locais. - Durante o Colóquio de Lisboa (setembro de 1961), o Almirante Guillén y Tato insistiu brilhantemente no interêsse de se conhecer todos os detalhes possíveis dos navios locais; pois, se alguns tiveram uso limitado, outros exerceram uma influência importante sôbre tipos gerais ou, ao contrário, testemunharam á sobrevivência de tipos antigos. Essa opinião logo teve dupla confirmação: uma, na comunicação do Sr. Jacques Bernard (Faculdade de Bordéus); a segunda, numa visita ao Museu de Lisboa, onde existe uma admirável coleção de tipos de barcos portuguêses.

Pôsto assim, parece que bastaria apresentar o problema para vê-lo resolvido. Entretanto, é preciso evidenciar logo uma dificuldade com a que se há de chocar o empreendimento. Os barcos locais que melhor se conhecem são os mais recentes (por exemplo, o "bâteau-boeuf" de Portugal, tão característico com seu conjunto de velas fantástico: dêle há uma maqueta, naturalmente, em Lisboa, e outra também no Museu de Ciências de Londres; viram-no navegar, os marinheiros do princípio do século; conhece-se com precisão o seu nascimento e a sua difusão, que provocou problemas e processos no decorrer do século XIX, problemas e processos de que se conservam vestígios.

Muitos dêsses barcos, que desapareceram há pouco tempo ou existem ainda (na França, lembraríamos os "thoniers", barcos de pesca do atum, os "bisquines", barco típico de Biscaia) (1), surgiram no século XIV, até mesmo depois da introdução do vapor. Sôbre êstes navios locais, verdadeiramente antigos, nossos conhecimentos são quase sempre mais limitados e esporádicos, quando não inexistentes.

Mas, como já dissemos para os instrumentos de pesca, mais vale procurar ser o mais completo possível sem sairmos, en- 
tretanto, do domínio do "Glossário" que é, antes de mais nada, a técnica naval, pois os pesquisadores futuros sempre poderão completá-lo.

\section{II). - Relações entre os grupos nacionais - e língua.}

O exemplo da palavra "Almirante", que se comenta a seguir, sugere imediatamente o tipo de relação que se deve estabelecer nas palavras dêste gênero de sentido complexo: os grupos nacionais terão que fazer a critica da parte geral e prever as modificações que estimarem necessárias; por outra parte, terão que redigir a parte concernente ao seu país.

Para a publicação, o problema é delicado. Inevitàvelmente, certos grupos nacionais atrasar-se-ão; outros não poderão ser constituídos... O ideal seria, certamente, prosseguir o desenvolvimento concernente ao Almirantes de França, com notícias sôbre os "almirantes" dos demais países... Seria isso possível?. Devemos desejá-lo, mas a solução depende do trabalho dos grupos nacionais.

No que concerne às demais palavras, o processo será pouco mais ou menos o mesmo, ficando entendido, todavia, que se poderá distinguir várias espécies de palavras:

Aquelas que, particulares à língua considerada, requerem apenas simples tradução.

Aquelas que, originárias da língua considerada, deverão ser objeto de uma ficha de base, estabelecida pelo grupo nacional.

Aquelas para as quais o problema fôr semelhante nos vários países, sugerimos o processo exposto mais adiante para a palavra "Almirante".

\section{Exemplo de palavra de sentido complexo.}

Na primeira série de diretrizes havia um certo número de exemplos, escolhidos por sua simplicidade; é o caso da maior parte das palavras que formam o JAL. Simplicidade, pois basta a data do aparecimento da palavra, seu sentido e a duração da sua vigência com algumas referências indispensáveis, que permitam justificar a acepção proposta. Mas nem tôdas as palavras são simples: há-as cuja história, para ser completa, exigiria uma copiosa tese, quando não várias (exemplo: "Almirante); outras há, cujo sentido evoluiu, adquirindo, sucessivamente ou coetâneamente, o sentido de coisas muito di- 
ferentes umas das outras (exemplo: "Caravela); há outras tão importantes que, freqüentemente, se vêem associadas a outras palavras, empregadas para precisar-lhes o sentido, o que implica uma grande complexidade (exemplo: "âncora").

E' evidente que as palavras desta ordem apresentam um problema particular, cuja solução deve ser perfeitamente clara. Ainda que não se trate de fazer uma enciclopédia, não podemos deixar de fazer um glossário histórico, isto é, que contenha a história das palavras; o pesquisador que as encontrar num determinado texto, deverá poder situá-las e compreendê-las de maneira satisfatória.

Como cada uma destas palavras traz, em si, um problema particular - o da sua própria história - não encontramos outra solução para determinar-lhes um método, senão tratando um exemplo. Três serão expostos a seguir, escolhidos porque pertencem à letra $\mathbf{A}$.

Naturalmente, são simples esquemas, que deverão ser completados através da precisão dos detalhes, algumas referências, e, sobretudo, citações... Mas o que se buscou de imediato, não foi uma redação definitiva das palavras em causa. $O$ trabalho é difícil. Nós oferecemos à apreciação dos interessados planos-modelos para que se aproveite o máximo das observações. O detalhe não é o mais importante (o que não significa que se deva negligenciá-lo), mas o sistema.

Os três exemplos apresentados satisfazem?

Permitem êles imaginar a maneira de construir outros sistemas que serão necessários para outras palavras complicadas? O trabalho de equipe, inaugurado com esta tentativa primeira, é que nô-lo dirá e permitirá, também, fazer as correções que se revelarem necessárias.

Devemos, em todo caso, precisar - e a palavra "âncora" é para isso um excelente exercício - a maneira de apresentar vinculadas as diferentes definições. Por exemplo, na definição de "âncora", é preciso referir-se à palavra "turco", que, por conseguinte, vai exigir a sua definição especial; a distribuição das definições se fará da seguinte maneira: na palavra "âncora", não se falará da palavra "turco" senão na medida em que fôr necessário conhecê-la para se compreender o que é uma "âcora de turco"; na palavra "turco", darse-á a definição exata ou as definições exatas desta palavra, a 
data do seu aparecimento, sua vigência, etc. No texto definitivo, as palavras assim tratadas deverão trazer uma sigla particular, indicando que elas têm uma definição especial no lugar que lhes corresponde na ordem alfabética.

\section{I. - ALMIRANTE.}

Substantivo masculino (plural: Almirantes). cisão.

...seguem as formas latinas e outras... datadas com pre-

Definição: Título com as respectvias significações, segundo as épocas e os países:

Oficial comandante de esquadra ou frota.

Oficial-mor da corôa.

Comandante em chefe da Marinha Militar exercendo autoridade superior no tocante à jurisdição marítima.

Grau superior dos Oficiais da Marinha (moderno).

\section{Origens:}

O têrmo de Almirante e o oficial que êle designa procedem de fontes sicilianas e genovesas. Desde 1170, existem na côrte normanda de Palermo um cargo outorgado ao chefe suprêmo das fôrças navais do reino, o de "Emir da afortunada esquadra real" (Almiratus regii fortunati stolii). Este cargo teve por titulares, sucessivamente, duas altas personalidades ítalo-normandas: Gautier de Modica (1170-1180) e Margarit de Brindisi (1180-1194); após a conquista do reino da Sicília pelos suábios, foram seus titulares marinheiros genoveses de alta linhagem: Guglielmo Grasso (1197-1201), Guglielmo Porco (1210-1221), Enrico de Malta (1221-1231). E' ao quarto dentre êles, Nicol Spinola, que o Imperador Frederico II dirige, quando da sua nomeação, em outubro de 1239 , ss primeiros regulamentos conhecidos do cargo de Almirante, as "Capitula pertinentia ad officium ammiratiae", que constituem o primeiro estatuto, organizando uma esquadra militar no Ocidente. Nêle, vemos o Almirante munido de uma autoridade superior que abrange todos os negócios da Marinha - organização, armamento, administração e comando da esquadra, alta jurisdição sôbre todo o pessoal marítimo - e as operações navais do reino. Os genoveses, que haviam adotado o título de "Amiratus" desde 1195 para designar os chefes (temporários ou comis- 
sionados) de suas esquadras, só conhecem o seu primeiro. Almirante estatutário em 1282; mas é imitando-os que êste título, tomado aos sicilianos, se impõe um pouco por tôda parte no Mediterrâneo e no Atlântico para qualificar os chefes das fôrças navais, no decorrer do século XIII, que é o período em que se organizam a maior parte das esquadras ocidentais. Na Inglaterra, Guilherme de Leyburn e Jean Bortetourte - depois de Luc de Thonay, em 1271 - são qualificados "Almirantes de navio" em 1295 e investidos, pela primeira vez, de extensos poderès, enquanto que Castela e Aragão possuiram um oficial semelhante, respectivamente, em 1254 e 1262 .

\section{França}

\section{A). - Os Almirantes temporários (1269-1342).}

Foi em 1269, por ocasião da sua segunda Cruzada, que São Luís designou o primeiro almirante francês, Florent de Varennes. Desde esta época o Almirante foi titular de um cargo que, todavia, não era provido permanentemente. Em 1295, a esquadra de Filipe IV esteve sob as ordens de dois "conduiseurs" (comandantes). Em dezembro de 1295, Otton de Coucy foi o primeiro almirante que comandou em Ponant. Nos anos seguintes, as operações foram conduzidas por almirantes genoveses, espanhóis ou franceses. A 7 de dezembro de 1335, Hue Quiéret tornou-se Almirante do mar sob as ordens do condestável Raoul d'Eu, capitão geral acima e diante de todos os demais da armada ("capitain général dessus et devant tous les autres de l'armée de la mer"). A Ordenança de fevereiro de 1342 tornou o Almirante independente do condestável, que não tem nenhum direito sôbre os assalariados do mar (" $n$ 'a nul droit sur les soudoier de la mer").

\section{B). - O Almirante da França de 1342 a 1626.}

O cargo de Almirante tendia então a tornar-se permanente. A Ordenança de 25 de março de 1351 deu-lhe o nome de Almirante da França e a Ordenança de 7 de dezembro de 1373, carta constitutiva do Almirantado da França, determinou suas atribuições, direitos e prerrogativas. A partir desta época o Almirantado enfeixou em suas mãos não sòmente o comando das esquadras reais, a direção dos arsenais e do pessoal civil e militar, mas também da justiça e da política marítima. O 
exercício dêstes poderes extremamente amplos era, entretanto, particular, ou melhor, autônomo, nas três Provínciàs recentemente incorporadas ao reino:

- A Guyenne tivera, entre 1295 e 1336, o seu Almirante particular, antes de vir a depender do Almirante da Inglaterra que também o era da Irlanda. Quando da sua incorporação ao reino da França (1451), ficou sob a jurisdição do Almirante da França; mas em 1469, recuperava ela o seu Almirante autônomo.

- A Provença não conhecera o cargo de Almirante senão a intervalos a partir do fim do século XIII. Após a sua anexação ao reino (1481), os poderes do Almirante foram reunidos ao cargo de Governador, ao passo que o comando da esquadra pertencia ao General de Galeras.

- Na Bretanha, apareceu um Almirante em 1320, investido, porém, só de poderes militares, ficando a jurisdição marítima sob a alçada da corôa ducal. Ao ser anexada à França (1491) a Bretanha conservou o seu Almirante particular, ainda que fôsse êle o próprio Almirnte de França por provisão especial, ou o Governador da Província.

Quando em 1614, Henri de Montmorency reuniu ao cargo de Almirante da França o de Almirante da Guyenne, seu poder tornou-se tão considerável que ombreou com o poder real. Richelieu conseguiu, em janeiro de 1627, a supressão do cargo de Almirante, que foi substituído pelo de Grão-Mestre, chefe e superintendente geral da Navegação e do Comércio da França, cargo que obteve para si. Dos almirantados provinciais, só subsistiu o Almirantado da Bretanha.

\section{C). - O restabelecimento do cargo (1669-1791).}

Com a morte do duque de Beaufort, último titular, o cargo de Grão-Mestre foi suprimido e restabelecido o cargo de Almirante, por um édito de novembro de 1669 , em favor de uma criança de dois anos de idade, o conde de Vermandois; sucedeu-o, em 1683, outro infante, êste de cinco anos, o conde de Toulouse: Quer dizer que o vérdadeiro chefe da Marinha era, então, o Secretário de Estado. Ao Almirante não sè outorgava poderes senão teóricos, tanto no campo administrativo e judiciário como no campo militar. De seu privilégio de comandar a principal armada naval, êle só podia usá- 
lo por ordem expressa do rei; o conde de Toulouse exerceuo uma só vez, em 1704. Honras especiais eram-lhe devidas, nos portos, onde, aliás, êle raramente aparecia. Competialhe executar as determinações e os regulamentos concernentes à Marinha que dependiam da sua assinatura; as nomeaçẽes dos oficiais de navio deviam igualmente estar revestidas de sua assinatura; eram simples formalidades. Ele presidia o Conselho das Prêsas mas aqui também prevalecia a influência do Secretário de Estado. Se exceptuarmos o curto episódio do Conselho da Marinha de 1718 a 1723, o cargo de Almirante não era mais do que uma rendosa sinecura.

Os direitos do Almirante eram efetivamente numerosos: direitos de licença, de matrícula, de ancoragem, de lastração e de deslastração; de fogos, tonelagens e balisas, de pequena tonelagem, etc... (ver estas palavras). Acrescente-se o produto dos naufrágios e dos salvados, das multas, confiscações e "seques res", o direito anual pago pelos diferentes oficiais das sedes do Almirantado, o direito do dízimo.

A arrecadação dêsses direitos todos, como o exercício de seu cargo, obrigavam o Almirante a rodear-se de uma administração, cujo chefe tinha o título de Secretário Geral da Marinha.

O cargo de Almirante da: França foi suprimido pela lei de 15 de maio de 1791 .

\section{D). - Depois Ida Revolução.}

O cargo de Almirante foi restabelecido a $1 .^{\circ}$ de fevereiro de 1805 , em favor de Murat, sob a reserva de que não se ocupasse dos negócios da Marinha. De 1815 a 1824 pertenceu êle ao duque de Angoulême e de 1825 até a sua extinção definitiva em 1830, ao Delfim.

\section{O grau de Almirante.}

Grau superior da hierarquia dos oficiais da Marinha, foi criado por uma lei de 15 de maio de 1791 , aliás, não aplicada; depois por uma decisão ministerial de 25 de outubro de 1795 , mas para ser atribuído só temporàriamente aos vice-almirantes encarregados de um comando importante. E' a Ordenança de 19 de agôsto de 1830 que o instituiu efetivamente: seu primeiro titular foi o Almirante Turdet, promovido a 19 
de março de 1831 e o último, o Almirante Tréhouard, promovido em 1869 .

\section{BIBLIOGRAFIA.}

BUFFET (A. F.) - - In "Guide des recherches dans les fonds judiciaires de l'Ancien Regime" (Paris, 1958, págs. 257-282).

CHASTENET d'ESTERRE (Jacques de). - Histoire de l'Amirauté en France (Paris, Pedone, 1906).

DARSEL (Joachim). - L'amirauté de Bretagne dès origines à la Révolution de 1789 (Tese de Letras na Sorbonne. Datilografada, 1954).

DAVID (Jean-Marc). - L'Amirauté de Provence et des mers du Levant (Marselha, Ged, 1942).

DUMAS (Auguste). - Etudo sur le Jugement des prises maritimes en France jusqu'à la suppression de l'office d'amiral (Paris, Larose, 1908).

GOURON (Marcel). - L'amirauté de Guienne, depuis le premier amiral en Guienne, jusqu'à la Révolution (Paris, Sirey, 1938).

MENAGER (Léon-Robert). - "Amiratus-a". L'émirat et les origines de l'amirauté (Paris, SEVPEN, 1960).

VIOLLET (Paul). - Le roi et ses ministres pendant les trois derniers siècles de la monarchie (Paris, Sirey, 1912).

Há uma lista dos Almirantes de França no "Glossário" de Du Cange (Paris, 1840, Tomo I, págs. 230-231).

A função do almirante nos demais países deverá ser transcrita, conforme forem sendo enviadas as notícias pelos correspondentes dêsses países.

\section{II. - ALMIRANTES: CASOS ESPECIAIS.}

(As rubricas seguintes serão objeto de uma pequena definição) .

\section{França}

- Almirante de Pôrto.

- Almirante comandante de uma esquadra ou frota.

- Almirante ide pesca.

- Almirante de combôio.

- Vice-almirante.

- etc... 


$$
\begin{gathered}
-404- \\
\text { III. - ALMIRANTE. }
\end{gathered}
$$

Adj. (f. e.) . ........ formas ..........

Definição: Particular ao Almirante.

França.

1). - Usado no seu sentido próprio:

- Nau almirante: navio almirante - o que leva a bandeira do Almirante (cf. Almirante comandante da esquadra ou frota).

- Pavilhão Almirante.

2). - Extensões:

Canonnier-amiral: canonnier-chef (séculos XVII e XVIII). Artilheiro-almirante: artilherio-chefe.

PAUL ADAIM, CDT. L. DENOIX, MENAGER, PERRICHET.

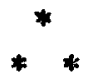

\section{ALMIRANTADO.}

\section{Definição:}

Funções que dizem respeito ao cargo de Almirante. Jurisdição marítima superior.

Por extensão, sede de ditas jurisdições.

\section{Origens:}

Em outubro de 1239, o Imperador Frederico II estabeleceu para o Reino da Sicília os "Capitula pertinentia ad officius ammiratiae", primeiro estatuto do cargo de almirante: êste é reconhecido como uma autoridade superior em tudo o que diz respeito à organização, armamento, administração e comando da esquadra, com alta jurisdição sôbre o pessoal marítimo e o comando das operações navais. Um estatuto análogo foi reconhecido ao almirante nos diversos reinos.

ALMIRANTADO (França) .

$\left.1 .^{\circ}\right)$. - Poderes judiciários e administrativos exercidos no âmbito marítimo pelo ou em nome do Almirante da França.

Definido pela Ordenança de dezembro de 1337, depois pelas Ordenanças de 1517, 1543, 1584, os poderes do Almirante 
comportavam ao lado da manutenção e do comando das esquadras navais reais, o conhecimento, a jurisdição, a correção e punição de todos os fatos do dito mar e dependência, criminal e civil (1337) ("la coignoissance, juridiction, correction e punition de tous les faits de la dite mer et dependance, criminellement et civillement" - 1337). E' esta jurisdição que se designa comumente com o nome de Almirarıtado. Jurisdição real, posto que exercida por delegação real, o almirantado é uma jurisdição ordinária. Goza de uma competência privativa, pois exclui o julgamento de qualquer outro juiz, e absoluta, por que ela não faz distinção de pessoas. Para exercer esta jurisdição, o Almirante é, desde meados do século XIV, secundado por oficiais particulares nos diferentes portos. A partir de 1544, êstes oficiais passaram a ser designados por cartas régias. A instituição do Almirantado tende, então, a evoluir de maneira autônoma, enfraquecidos os laços que a ligavam à pessoa do Almirante, o qual, finalmente, se vê substituído pelo Grão-Mestre, de 1626 a 1669 . Ao iniciar-se o reino pessoal de Luís XIV, a marinha real subtrai-se à competência do Almirantado; mas a Ordenança de agôsto de 1681 outorgathe poderes de livre ação sôbre tôda a navegação comercial.

\section{A). - As Sedes dos Almirantados.}

Desde meados do século XIV, o Almirantado delegou, nos portos, lugares-tenentes, particulares ou gerais, que faziam justiça em seu nome. No plano local, êsses Almirantados particulares fizeram, por muito tempo, concorrência às outras jurisdições ordinárias, senhoriais ou reais. A apelação de suas sentenças era feita perante a Sede Geral do Almirantado de França, que tinha assento em Paris, no Tribunal do Palácio (à la Table de Marbre du Palais), e que podia julgar, igualmente, certos casos em primeira instância. Mas a jurisdição soberana continuava sendo o Parlamento, ao qual era diretamente confiada a apelação, em matéria criminal. Por outra parte, a competência do Tribunal de Paris era, singularmente, restrita: a Normândia não dependia da sua jurisdição, onde uma Sede Geral de Tribunal de Justiça, análoga à de $\mathrm{Pa}$ ris, havia sido fundada em 1508; o mesmo acontecia com a Bretanha, a Guyenne, e tôda a costa mediterrânea e Dunquerque inclusive, desde 1647. O que quer dizer que os oficiais do Tribunal de Paris, nos séculos XVII e XVIII, ficaram sem funções. ("sans plus aucune fonctions"). Os tribunais particula- 
res, ao contrário, guardaram tôda a sua importância. Êles foram criados em épocas diferentes consoante as regiões, os últimos na Bretanha em 1691 (que dependiam do governador da Bretanha e não do Almirante de França; e a justiça era feita em nome do rei). No fim do Antigo Regime, contava-se, nas costas da França, um total de 50 tribunais particulares de Almirantado (lista in "Buffet, loc. cit., págs. 270-274). Outros tribunais de Almirantado foram instalados nas Colônias.

$O$ pessoal das sedes tinha em quase tôda parte a mesma composição, normalizada por um édito de junho de 1669: um capitão-tenente, nas funções de magistrado civil e criminal; um primeiro-tenente, ajudante; quatro conselheiros, um procurador do rei, um advogado do rei, um escrivão e dois oficiais de diligências. Havia ainda, em cada Almirantado, um recebedor que arrecadava os direitos de Almirante e lhes dava seguimento. Em numerosos portos oblíquos (portos em que não havia sede de Almirantado), delegava-se um oficial-escrivão, que expedia as licenças para a cabotagem e a pesca do peixe fresco e, ao mesmo tempo, coletava os direitos de Almirante.

\section{B) . - Da sua competência.}

Como é normal sob o Antigo Regime, competência e poderes administrativos estavam estreitamente ligados.

\section{a). - Jurisdição civil e criminal.}

E' no direito de correção sôbre os marítimos, direito de que dispunha desde o primeiro terço do século XIV, onde se deve buscar a origem dos poderes de justiça exercidos pelo Almirante, prerrogativa que ampliou posteriormente com a competência de conhecer, julgar e deliberar sôbre todos os crimes cometidos no mar, portos e enseadas, e sôbre as costas (exceptuavam os barcos e arsenais do rei, que, depois de 1669, não estavam sujeitos à sua jurisdição).

A essa prerrogativa penal juntou-se uma ampla competência em matéria civil, incluindo todos os contratos marítimos ou que implicassem na responsabilidade de um homem do mar: fretamento, garantias, seguros, empréstimo a risco total, companhia de comércio, etc... Mas, neste domínio, as jurisdições dos juízes e cônsules ou das câmaras de comércio destituiram, em parte; os almirantados.

Aos oficiais do Almirantado competia, por outra parte, a execução dos julgamentos concernentes às prêsas. 
b). - Policiamento da navegação.

Pela outorga das cartas ou títulos de licenças, pelo registro das cartas de corso, das comissões de armar em guerra e na paz e pelo registro das mercadorias, os almirantados controlaram todo o tráfego marítimo e todos os negócios. Recebiam igualmente as declarações de compra ou de construção de navios, procedendo à vistoria das embarcações, na entrada como na saída, e pronunciavam, se necessário, a sua condenação. Registravam os relatórios dos capitães, quando de seus regressos. Fiscalizavam o embarque dos passageiros (inclusive o dos protestantes fugitivos após à revocação do édito de Nantes), e, por extensão, encarregavam-se do policiamento dos negros como da vigilância dos estrangeiros. Enfim, procediam ao exame e à recepção dos capitães, dos mestres de navio, pilotos e demais mestres dos diversos corpos de ofícios da construção naval.

\section{c). - Policiamento dos portos e enseadas.}

Fiscalização dos pilotos, das operações de lastração e deslastração, do estado dos diques e paredões de segurança dos ancoradouros, tarefas essas que, no mais das vêzes, eram executadas por um mestre do cais, nomeado pelo Almirante.

\section{d). - Policiamento das costas.}

Primitivamente, era prerrogativa do Almirante a organização, em tempo de paz como na guerra, do serviço de ronda requerido pelos habitantes das costas (Carta de Carlos VI de 23 de outubro de 1399 e Ordenança de 1584). O serviço da guarda-costa dependeu posteriormente da Marinha ou do Exército, mas os oficiais guarda-costas continuaram a prestar juramento diante dos oficiais do Almirantado. Estes procediam ao levantamento dos cadáveres dos afogados, tomavam conhecimento dos naufrágios e e dos salvados, do corte e colheita do sargaço. Competia-lhes, enfim, mais particularmente, a fiscalização da pesca e de seus instrumentos.

Depois de 1669 , os oficiais do Almirantado, por tôdas essas funções administrativas, dependiam, na prática, menos do Almirante do que do Secretário de Estado da Marinha, e sua autoridade encontrava a concorrência da dos comissários e funcionários das classes. 
A assembléia Constituinte suprimiu, em princípio, os almirantados pelo decreto de 6 de setembro de 1790 . A lei de 13 de agôsto de 1791 distribuiu as suas atribuições' as atribuições judiciárias passaram para as jurisdiçōes comerciais, administrativas ou de direito comum; as atribuições administrativas foram divididas entre a Marinha Nacional, os Trabalhos Públicos e as Finanças.

PAUL ADAM, COMTE L. DENOIX, MENAGER, PERRICHET.

Bibliografia: a mesma indicada para "Almirante".

DARSEL (J.). - Caen, siège particulier d'amirauté", Rev. hist. de Droit fr. et étr., 1958, pág. 148 .

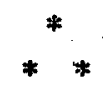

ANCORA.

(do lat. ancora)...

Âncora é uma peça composta de uma haste (ou tronco) denominada verga, tendo numa extremidade dois braços que terminam ou não pelas patas; na outra extremidade, sujeitase um cabo ou corrente seja diretamente seja por meio de uma argola: o arganéu. Atravessado no plano em que se acham as patas, quase sempre na extremidade oposta, há uma travessa fixa ou móvel - o cepo - que, quando pousa no fundo do mar ou do rio, obriga uma das patas a dispor-se de maneira a penetrar fundo no solo, quando o navio força o cabo. As âncoras, sobretudo as antigas, têm, geralmente, uma manilha fixa no topo da verga, na mesma extremidade em que se acham as patas. Estas reunem-se no cabeço da verga, e a âncora termina numa ponta chamada cruz. Na cruz, as âncoras antigas traziam fixa uma manilha.

As âncoras podem ser de madeira, ferro forjado ou ferro. $\mathrm{O}$ cepo pode ser de madeira ou de ferro. Na época romana, encontramos cepos de chumbo em âncoras de madeira.

As mais antigas representações conhecidas encontram-se num vaso grego de cêrca de 550 a. C. e em moedas do V século. O prolongamento dos braços aparece no primeiro século depois de Cristo. Antes do aparecimento da âncora, prendiamse os navios com pêsos constituídos de um cesto ou caixà de madeira cheios de pedras ou de metais. Deodoro da Sicília 
conta que os fenícios que aí aportaram, trazendo, em suas primeiras viagens, carregamento de ouro e prata, substituiam o metal de seus pêsos de amarra peḷo ouro e prata de sua carga.

Quanto ao aparelho destinado a aferrar a embarcação a algumas braças, é chamado arpéu, gancho de ferro, etc... jamais âncora.

Quando as âncoras possuem uma só pata, recebem o nome de "cega" (antigo) ou de corpo morto; são colocadas em ponto fixo para servir de posto de amarra; a supressão de uma das patas permite utilizá-las em lugares pouco profundos sem perigo de que os navios venham arrebentar a sua querena (ou casco) na pata superior da âncora.

A âncora está pousada (antigo), lançada ou molhada (moderno); diz-se de um navio na âncora, ancorado, ou que repousa sôbre a âncora... A âncora morde ou agarra, crava ou aferra.

Muito embaraçoso é quando a âncora fica "surjalée", isto é, quando o cabo enrola-se no cepo, e, mais grave ainda, quando êle enrosca-se numa das patas (surpatiée, em francês): em ambos os casos, será difícil trazê-la a bordo, ao içarem-na; no segundo, sobretudo, porque não se firmará bem no solo.

Quando içada pelo navio que puxa os cabos, a âncora vem a pique, a prumo ou verticalmente; ela iderrapa, desaferra ou desgarra quando é arrancada do fundo e deixa (antigo) quando sarpa ou zarpa; içada ou alçada oü levantada, quando a vemos fora dágua; e limpa, quando não vem enroscada no cabo.

Antigamente, as âncoras pesadas ou leves eram arrancadas do fundo por uma chalupa, que atuava sôbre um arinque (cabo) amarrado diretamente numa argola fixa na cruz da verga, isto é, que puxava pela extremidade da âncora, oposta àquela em que está prêso o cabo que a têm ligada ao navio. Diz-se, então, que a âncora vem erguida pelos cabelos. A razão desta manobra é que, ao se puxarem os cabos de uma âncora, uma de cujas patas agarrou sòlidamente o fundo, faz-se trabalhar a âncora como uma alavanca, obrigando-a a suportar um esfôrço, que poderá ser considerável; não é, pois, senão a partir do momento em que o metal forjado permitiu fabricar âncoras pesadas e sólidas, e em que o emprêgo das correntes generalizou-se, que essas manobras, auxiliadas por uma chalupa, foram progressivamente abandonadas. Usam-na, no entanto, ainda, quando a âncora recusa-se a abandonar o fundo. 
Os navios, e sobretudo os navios antigos, sempre levaram a bordo um número elevado de âncoras de tamanhos diversos. (Na Idade Média, por exemplo, era normal embarcar pelo menos 8 âncoras de fundear). Este hábito provinha dás dificuldades de levantamento ou da ruptura dos cabos que obrigavam a abandonar as âncoras ou a perdê-las com freqüência. Ainda hoje, os navios de pesquisas oceanográficas, que ancoram em profundidades de vários milhares de metros, perdem muitas âncoras; e uma técnica recente de âncoras explosivas permite fundear um navio importante com uma âncora de tamanho ridículo, a qual, funcionando como um obus, penetra fundo no solo, e, naturalmente, se perde quando o navio zarpa.

\section{Tipos de âncoras.}

As âncoras recebiam inúmeros qualificativos, segundo sua posição a bordo do navio ou o uso que delas se fazia. Ademais, tinham elas, naturalmente, vários tamanhos. Por ordem de tamanho, pode-se indicar:

a) . - âncora de misericórdia, de salvação ou mestra: é, a bordo de uma embarcação, a âncora mais pesada, utilizada como socôrro, em caso de perigo extremo; fica situada no fundo do porão, bem no centro do navio.

b). - âncora de turco ou de emergência ou sobressalente, isto é, âncora instalada no turco (aparelho que ergue a âncora), pronta a servir ou para ser lançada ao mar; são âncoras de tamanho médio, das que servem para lançamento ou ancoragem normais. nobras:

c). - as mais pequenas servem para as mais diversas ma-

âncora de arremêsso, que se transporta em chalupa a um dado lugar e que serve de ponto fixo para modificar a orientação de um navio já ancorado; é ainda aquela que se lança a alguma distância de um navio encalhado e na qual se apóia êle ao tentar desencalhar.

âncora de reboque (ou de tração): aquela que se lançava a alguma distância do navio e em que era rebocado; podia-se utilizar várias ao mesmo tempo, ficando rebocado numa o navio, enquanto a chalupa levava outra mais adiante e assim por diante. 
âncora de "empennelage": âncora de pequena dimensão que se lança antes e diante de uma outra mais pesada que, sem aquela, arriscaria fugir ou desgarrar-se; o efeito é tal que uma âncora de "empennelage" de uma tonelada, unida àquela de 8 toneladas, pode assegurar uma capacidade semelhante a de uma âncora de 16 toneladas; a razão está em que a menor obriga a âncora mais pesada a colar-se ao fundo, aumentando-lhe assim a sua eficácia de maneira considerável.

Acrescentemos ainda que uma âncora de arremêsso de um navio grande podia ser utilizada como âncora mestra de um navio pequeno, ou como âncora de fundear de. um navio médio. De sorte que, a denominação da âncora não nos informa sôbre o seu tamanho senão de maneira relativa.

\section{Manobras da âncora.}

A âncora fundeada ou levantada por uma chalupa era, evidentemente, de tamanho bastante grande ou até mesmo considerável com respeito à chalupa. Donde advém tôda uma série de manobras diferentes que deu lugar a um vocabulário especial. Citemos, por exemplo, a chalupa que conduzia a âncora a reboque (suspensa fora, no costado da pôpa) ou "en cravate": (com um dos braços do cepo pousado sôbre a pôpa, perpendicularmente a esta).

Por outra parte, estas manobras davam lugar à prática das manobras de cordame e dos cabos com seus variados nós (nó de arinque, "d'empennelage"). Havia até combinação de dois nós. Por exemplo, quando a chalupa embarcava uma âncora, não podia içá-la de uma só vez; levantavam-na paulatinamente, progressivamente, com o auxílio de nós sucessivos ao longo da verga, cortando-se o cordame quando o nó chegava à altura do alcatrate da chalupa, até que fôsse possível puxá-la para dentro.

Bibliografia: Para a história da âncora: cf. "Mariner's Mirror...".

Para as manobras da âncora: Manuel Gabier, de 1910, que traz uma parte antiga, retomando o manual eqüivalente do princípio do século precedente e que contém, igualmente, todos os pormenores das manobras feitas com o auxilio das correntes, cujo emprêgo se generalizara por volta de 1830 .

Âncora (Iconografia desejável). 
Desenhos ilustrativos:

1). -- esquema tipo de uma âncora com a indicação de suas diferentes partes;

2). - esquema do içamento de uma âncora a bordo de uma chalupa.

\section{Reprodução:}

1). - Algumas âncoras de tipos diversos.

2). - E se possível, uma reprodução de Van Velde, mostrando navios cujas chalupas içam as âncoras.

\section{CDT. L. DENOIX E PAUL ADAM}

